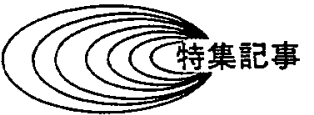

\title{
GPSの原理と地震予知への応用*
}

畑中 雄 樹**

\section{Principle of GPS and its Application to Earthquake Prediction}

\author{
Yuki HATANAKA
}

\section{1. はじめに}

「地震はなぜ起きるか」という疑問に対して， プレートテクトニクスは「沈み込む海洋プレート に引きずり込まれた陸側のプレートが耐えきれな くなって反発するのだ」と説明する。これは，正 確には海溝沿いに起きる大地震についての説明で ある。プレートテクトニクスは，海洋底に記録さ れた地磁気の縞模様, 地震のメカニズム解, その 他のさまざまな地球物理的証拠から，1960年代に 確立されたパラダイムだが, プレート運動を測地 学的に実測できるようになったのは, VLBIや GPSなどの宇宙測地技術が現れてからの話であ る。これらの技術によって, プレート運動が可視 化されたと言えるかもしれない。特にGPSは，技 術開発によってその精度が格段に向上し, 更に扱 いが簡便で機動性に富みコストも低いことなどか ら, 近年, 地殼変動観測の主流になり, 地震予知 への応用も有望視されるようになってきた。

本稿では, GPS測量の原理について簡単に解説 し，国土地理院で構築した全国GPS連続観測シス テムについて紹介し，その地震予知における意義 について論じる。

\section{GPSの原理}

GPSは，元来ナビゲーションを目的とした軍事 技術を，民間にも部分的に解放して使用できるよ うにしたシステムである。まず，その原理を単純

*原稿受付 1996年 1 月 16 日

**国土地理院
化して説明する。

地球の周りを回る24個のGPS衛星から地上に 向けて電波が送信されている。衛星には正確な原 子時計が搭載されており，この時計の読みや衛星 軌道の情報が，電波に烡せて放送されている。地 上の観測点では，GPS受信機でGPS衛星からの電 波を受信し，受信機内部の時計で測定される受信 時刻と, 衛星での発信時刻の差の情報から衛星一 受信機間の距離を計算し，受信機の位置を決定す る。同時に四つ以上の衛星が観測されれば，瞬時 に位置がわかる仕組みである。この方法は単独測 位法と言い，十ビゲージョシに使用されている。 その精度は数十m以内で，測地測量には不十分で ある。

测地測量で使用される方法は相対測位法といい， (1)コード化された信号の情報を使用するのではな く,より分解能の高い電波の位相を測定すること, (2)複数の観测点で同時に観測を行い, 後でデータ を持ち寄ってコンピュータで解析すること，(3)同 時に観测された複数の観測点・衛星のデー夕を差 し引き計算を行って，かなりの誤差要因を減らす こと，(4)観剆点の絶対位置ではなく，2 点間の相 対位置が求められること, が単独測位法と大きく 異なる点である。相対測位法の精度は，通常 $1 \mathrm{ppm}$ （10kmの基線を $1 \mathrm{~cm} の$ 精度で測定）程度である が，最先端の技術を駆使すると数ppb (1000kmの 基線を数mmで測定）の精度を達成することが可 能である。このような高い精度は，GPS衛星の精 密軌道情報の使用や，電波の伝播時間に影響を与 える大気遅延量の推定などの多くの䛊差姴因を慎 
重に考慮することによって初めて達成 できるものである。

\section{3. 全国GPS連続観測網 (GRAPES)}

1994年10月，国土地理院は，地殼変 動の監視と測量の基準点としての使用 を目的として，全国GPS連続観湘シス テム (GRAPES; GPS Regional Array for PrEcise Surveying/Physical Earth Science)を整備した1”。またこ れに先立ち, 関東東海地域に地震予知 を目的としたGPS連続観測網 (COSMOS-G2)が配備されているが2)，ここ では前者を中心に紹介する。

全国に配置された100点のGPS固定

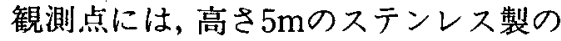
タワーが設置され，その頂上にはアンテナが，胴 体内には受信機と通信機器，及び停電用のバッテ リ一が格納されている。観測点では，GPS衛星か らのデータを，30秒のサンプリング間隔で24時間 連続的に記録している。観測されたデー夕は，公 衆電話回線によって，茨城県つくば市の国土地理 院内にあるGPS解析室に転送される。GPS解析室 に集められたデータは，マサチューセッツ工科大 学とスクリプス海洋研究所で開発されたGAMIT /GLOBKと呼ばれる精密GPS解析ソフトウエア を使って解析され，日々の観測点の位置が得られ る。これらの作業は，システムが自動的に行うよ うになっている。

この全国GPS連続観測システムの完成以来，北 海道東方沖地震 (1994年10月4日，M8.2)，三陸は るか沖地震（1994年12月28日，M7.5），兵庫県南 部地震（1995年1月17日，M7.2）と，日本列島は 立て続けに大きな地震に見舞われた。奇しくも， これらの地震によって，完成したばかりのシステ ムの赛力が試されることとなった。

Fig. 1はここの観測網で捉えられた兵庫県南部 地震に伴う地殼変動である。地震によって，大阪 府筫面市の観測点が西に $3 \mathrm{~cm}$, 兵庫県御津町の観 測点が東に $3 \mathrm{~cm}$ 移動しているのがはっきりと捉え られている。その精度は, 水平成分で数 $\mathrm{mm}$, 鉛直 成分で1-2cmである。これは，相対精度にすると従 来の測量方法を 2 桁以上も上回るものである。こ の図から震源付近が東西方向に圧縮されているの が読みとれる他，よく見ると南北方向への伸長も 見られる。求められた地殼変動は, 地震の震源モ デルを推定する上で基本的なデータとなる。北海 道東方沖地震や三陸はるか沖地震の場合も，同様 の地震時の変動を地震発生後数日で求めることが できた。これは地殼変動の観測にとって画期的な 進歩である。従来ならば，地震が発生した後に観 測計画を立てて，現地に赴き，光波測距儀やトラ ンシット等で何日もかけて测量を行い，観測結果 を点検し，計算して，最終的な地殼変動がでるま で，何週間もかかっていたのである。GRAPESの 登場によって，地震による地殼変動の大まかな様 子を数日のうちに把握できる体制が整った。この ような迅速な対応は，地震を物理的に解釈するた めの資料を提供する上でも，また震災後の復旧測 量のための测量計画をたてるうえでも重要である。

GPS連続観測の重要性は，地震発生後に即対応 できるというだけではなく，地震による地款変動 の把握をより正確にするという面にもある。測地 測量でわかる地殼変動というものは，地震後の観 測点の位置と地震前の観測点の位置の差である。 従来の測量では，大地震の発生後にはその直後に 
観測をすることができるが，地震前のデー夕は何 年も前に観測したものであるのが普通であった。 したがって，そのデータから求められる地殼変動 は，地震時の瞬間的な変動以外の変動が含まれる 可能性が高い。それに対して，GRAPESによって 得られた地款変動は, 地震の直前直後のデータが 連続的に記録されているので，まさに地震の瞬間 の変動を捉えているということができるのである。 地殼変動を連続的に監視できるということは, 地震時の瞬間的な地面の動きをとらえるだけでは なく，長期的で緩慢な動きを捉えることも可能に する。Fig. 2は, 三陸はるか沖地震の前後の青森県 久慈市の観測点の動き（宮城県利府町に対する相 对的な変位)である 明瞭なジャンプの他に, 明らかに余効変動と思わ れるなだらかな変動が見られる。このようなゆっ くりとした変動は, 時間的に密で, かつ精度の高 い観測を行うことによって，初めて捉えられるも のである。国土地理院では，定常的なプレート運 動あるいはプレートの変形をモニターし, 日本の 地殼変動の速度場を求好研究も行われている4。

以上, いくつかの例で見てきたように, GRAPESは即応性, 時間分解能, 継続性の点で,

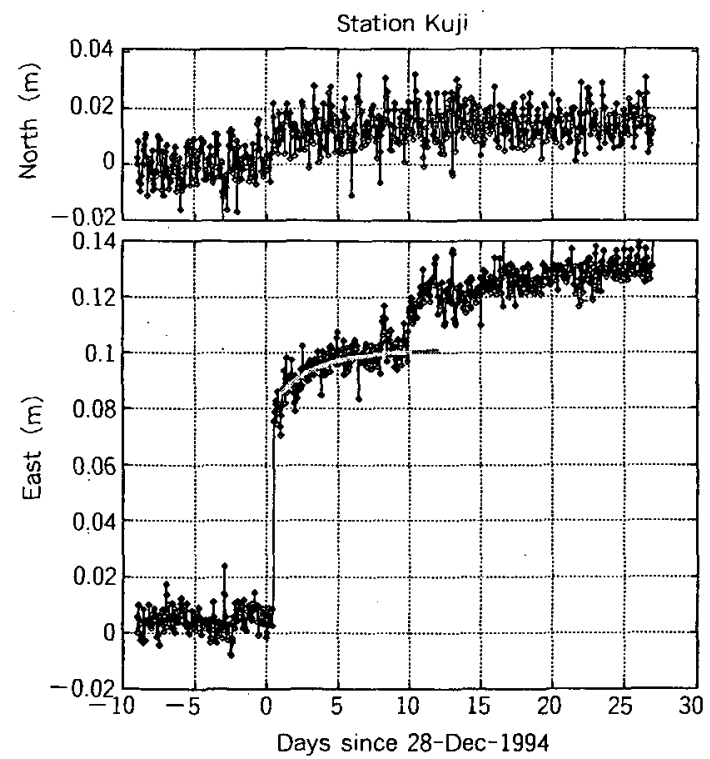

Fig. 2 Horizontal crustal deformation associated with the 1995 Hyougo-ken Nanbu earthquake. The arrows show the displacement vectors relative to Touhaku station.
今までの地殻変動観測では考えられない汪ど高い 能力を持っている。平成 7 年度中には, GRAPES とCOSMOS-G2が拡張統合され，全部で約610点 のGPS連続観測網という，世界でも例を見ない高 密度な観測網になる(Fig.3)。これによって日本全 国が，平均点間距離25-30kmのGPS観測網に覆わ れることになる。時間空間的に密度の高い観測に よって，地震の前兆的地殻変動の検出率を高める ことができる。また，日本列島のより詳細な地狮 変動を把握することによって，日本の活構造や地 震活動との関連を論じることも可能になるだろう。

\section{4. 地殼变動の表示方法}

計算によって求められた地殻変動から情報を読 みとり洞察を得るためには，地殼変動を図示する 必要がある。

地款変動を図示するには，Fig. 1のような観測 点の変位を矢印で表したべクトル図がわかりやす い。この図では鳥取県東伯町の観測点を固定して, この点との相対変位を表示している。これは，グ ローバルな座標系で変位を見た場合には, 誤差が 比較的大きく，あまり離れていない観測点間の相

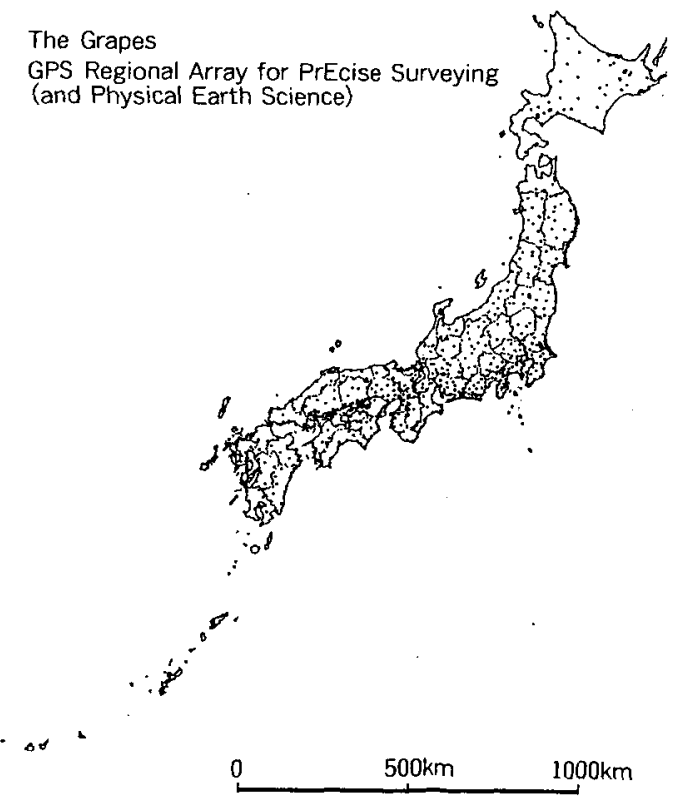

Fig. 3 Location of the observation stations of GRAPES after the expansion and integration of current GPS networks (to be finished in March, 1996). 
対変位の方が正確に求められるためである。実際 に相対変位を求めるにはどこかを固定する必要が あるが, 固定点の選択には任意性がある。地震に 伴う変動を見る場合には，震源から遠く離れてい る観測点を近似的に不動とみなすことにより，こ の問題を一応避けることができる。しかし，例之 ば長期にわたるデータからプレートの定常的な変 動を求めて表示するような場合は，どの点も不動 とはみなせないので，任意性が残る。言い換えれ ば、ベクトルによる困を見る際には，定べクトル のバイアスがかかっている可能性を意識して見な ければならない。

一方, 相対的な変動の様子を表す物理量として, 歪みを図示する方法もある。歪みは 2 階のテンソ ル量なので，それをわかりやすく表示するのは容 易ではない。そのため，いくつかの仮定を置いて 問題を単純にするのが普通である。まず, 弾性論 における自由表面の境界条件の性質から，地表付 近では雪みテンソルの主軸の一つが鉛直方向を向 き，残りの 2 軸が水平面内にあると仮定する。更 に三つの観测点を頂点とする三角形を構成し，三 角形内で歪みが一様であるという仮定をすると， 各頂点で与えられた変位から歪みの水平成分を計 算することができる。このようにして求めた水平 歪みのテンソル主軸をその大きさと共に地四上に 表示するというのが，よく行われる方法である。 この方法は, 観測点で与えられたデータを補間す る必要がないので, 観測点の密度が低い場合でも 三角形内の歪みを一意的に決めることができると いう利点を持っている。また, 歪みについての多 くの情報を一度に表現できるという強みもある。 ただし，三角形を構成する観測点の選択には任意 性がある。

観測点で与えられた変位を, 補間によって格子 点データに直し，グリッドやワイヤーフレームで 表示する方法も提案されている5)。観測点の数が 增えて，その密度が高くなってくると，グリッド 化による䛊差が小さくなることが期待される。グ リッド状に亚んだ点列の変動パターンを眺めるこ とによって, 地面の変位が場所によって変化して いる様子を直感的に捉えることができる。

今のところ, 地殼変動をその時間変化まで含め
て可視化する究極の表示方法はないようである。 よりよい表示方法の出現が望まれるが，むしろ， いろいろな表示方法を，それぞれの長所を生かし て使い分けるべきなのかもしれない。

\section{5. 地震予知に向けて}

地殻変動観測を地震予知に役立てるには，地殼 の実際の動きを逐次モニターすると同時に，得ら れた変動が何を意味するのかを解釈することが重 要である。つまり，地殼の異常な変動を検知する ことも大切だが，それと地震との閒の関係を適切 に解釈するためのモデルがなくてはならない。地 震の前兆的地殼変動には短期的なものや長期的な ものがあるが，これは過去に地殼変動を捉えた数 少ない貴重な観測デー夕を実際に発生した地震と 対応させることによって，前兆であることが判っ たものである。実戦では，地震が発生するという 未来の情報がないので，客観的な判断をするには， その拠り所となる物理的なモデルが必要である。 モデルを構築するには，数多くのデータを蓄積し てその中から普遍的な法則を引き出さなければな らない。GPSによる地殼変動の連続観測は、この ような面からも今までにない視野を提供するもの である。地震予知を地殻変動観測の立場から見る と，主として日単位から年単位の現象がターゲッ トであると考えられるが,このタイムスケールの 現象を時間空間的にこれはど密にモニターする手 段はこれまでなかったのである。全国GPS連続観 测網によって，我々はこの夕イムスケールの現象 を見るための新しい「目」を持つに至ったと言え よう。

一般にモデルには，互いに関連する二つの目的 がある。現象の予測と, 現象の本質の理解である。 地震予知に即していえば，地震の発生を予测する ことが前者であり, 地震発生のメカニズムを明ら かにすることは後者である。地震発生のメカニズ ムには，まだ謎の点が多いが，地殸に加えられて いる広域的な応力がその原動力である。現状では 地震発生域の地款応力を直接連続的に測定するこ とはできないが，モデルによってGPSで得られる 地表変形の情報と結びつけることは可能である。 問題は, モデルの構築にある。地球内部の地震波 
の伝わり方や地震時の地殼変動などの短期的な性 質は，地球が第一近似的に弾性体であると考える とよく説明できるが，長期的には非弾性的な振る 舞いもするだろう。実際，三陸はるか沖地震では GPS連続観測によって長期的な余効変動が観測 されたが，その原因としてアセノスフェアの粘弾 性的変形の可能性を示唆する研究もある6)。この ような非弹性的変形の性質は，まだ十分に解明さ れておらず，むしろGPS連続観測デー夕を基にし て，これから研究が進められるべきものである。

プレート境界で発生する地震について，その繰 り返し期間にわたる長期的な地殼変動を断層面上 の滑りと関係つけて諭じられるようになったのも 最近のことである7。地震の繰り返しサイクルを 理解するためには，広域的な地殼変動を長期にわ たって把握することが大切である。これは，GPS 連続観測網のデータが蓄積するのを待てば自然に 実現されるはずである。それだけではなく，地殻 変動の時空間的に微細な構造を捉えることによっ て，活構造や微小地震の発生，その他の地球物理 学的な現象間の相関が明らかになるかもしれない。

以上のような,さまざまな研究を進めていくこ とによって，日本列島の地殼変動のモデルが構築 され，いいてはより確かな地震予知へのステップ となるであろう。

\section{6. 終わりに}

本稿では，地殻変動観測に的を絞ったが，GPS 連続観測網の可能性はそれだけに留まらない。大 気中の水蒸気によってGPSの電波が途延を受け
る性質を利用して天気予報に応用するGPS気象 学, GPSによる電離層モニタリングやGPSを地震 計として使用する可能性など，はば広い応用が可 能である。これはGPS技術そのものの沉用性と高 密度な連続観測の相乗効果によるものと言えよう。 謝 辞

本文推敲にあたって，国土地理院地殼調査部の 橋本学氏および晸谷威氏から貴重なコメントをい ただいた。

\section{参考文献}

1) Miyazaki S., H. Tsuji, Y. Hatanaka, Y. Abe, A. Yoshimura, K. Kamada, K. Kobayashi, H. Morishita and Y. Iimura : Establishment of the Nationwide GPS Array (GRAPES) and its Initial Results on the Crustal Deformation of Japan, Bulletin of the Geographical Survey Institute, 1996, in press.

2) Sagiya T., A. Yoshimura, E. Iwata, K. Abe, I. Kimura, K. Uemura and T.Tada: Establishment of Permanent GPS Observation Network and Crustal Deformation Monitoring in the Southern Kanto and Tokai Areas., Bulletin of the Geographical Survey Institute, Vol.41, 1995, 105-118.

3 ）辻 宏道, 畑中雄樹, 官崎真一,F、ウェブ：GPS連続観测で 見た三陸はるか沖地震の広域的な余効変動, 日本地震学会講 演子稿集，1995年度秋期大会，1995，P102。

4) 営崎真一, 过 宏道, 畑中雄樹：GPSで観测された日本の地 款変動速度場, 日本地震学会講演子稿集, 1995年度秋期大 会, $1995, \mathrm{C} 81$.

5 ) 海津 優, 星野 実: 高密度変位デ一夕から求めた地葋歪み の表現方法、日本测地学会第84回講演会要旨, 1995, 23-24.

6) 日置幸介，中井新二：GPSで見る地震時/地震後地竞変動： 三陸はるか沖地震 $(1994 / 12 / 28 \mathrm{Mw}=7.6)$ の特異性とその 地学的意義, 日本測地学会第84回講演会要旨, 1995, 101102 .

7) Sagiya T. : Crustal Deformation Cycle and Interplate Coupling in Shikoku, Southwest Japan., 東京大学博士 論文, 1995 . 